\title{
Changes in numbers and distribution of wintering Long-tailed Ducks Clangula hyemalis in Swedish waters during the last fifty years
}

\author{
Förändringar i antal och utbredning hos övervintrande alfåglar Clangula \\ hyemalis $i$ svenska farvatten under de senaste femtio åren
}

\author{
LEIF NILSSON
}

\begin{abstract}
The Long-tailed Duck Clangula hyemalis is the most common wintering waterfowl in Swedish marine waters but it is not well covered in the International Midwinter Counts due to its offshore distribution making special surveys necessary for the species. Surveys covering the entire Baltic Sea were organized for the first time in 1992/1993 with follow-up surveys in 2007-2011 and 2016. In Sweden, aerial line transect surveys covered all areas of importance for the Long-tailed Duck during the last two all-Baltic surveys. In the 1970 s extensive regional surveys were done from coastguard boats and airplane. The total wintering population of Long-tailed Duck was estimated to be around 370,000 individuals in 2016 com-

pared to 436,000 in 2009 , and in the order of 1,400,000 in $1992 / 1993$, indicating an ongoing decrease. Comparing the more recent surveys with the surveys from the 1970 s, the most marked changes in wintering numbers were found east of Gotland, where only a small proportion of the numbers estimated in the 1970 s remained. Decreases were also found in the waters around Öland, whereas no marked changes were noted for the smaller wintering populations of the east coast archipelagos.

Leif Nilsson, Biological Institute, Biodiversity, Lund University, Ecology Building, S-223 62 Lund, Sweden. Leif. Nilsson@biol.lu.se
\end{abstract}

\section{Abstract}

Received 13 October 2016, Accepted 8 November 2016, Editor: S. Svensson

\section{Introduction}

The Long-tailed Duck Clangula hyemalis is the most common wintering waterbird in Swedish waters but due to its marine distribution it is not so well covered in the Midwinter Counts organized annually since 1967 (Nilsson 1972, 1975, 1980, 2012, Nilsson \& Haas 2016). Proper monitoring of the Long-tailed Duck requires special surveys in the archipelagos and the offshore areas.

During the years 1965-1978 more than 100 boat surveys were undertaken along the Swedish coasts from the patrol boats of the Swedish Coast Guard (Nilsson 1972, 1980). Extensive aerial surveys were also undertaken mainly in the archipelagos but also along the open coasts of Scania, Öland and Gotland (Nilsson 1975, 1980). It was however not possible to survey the Midsjö Banks and Hoburg Bank far out in the middle of the Baltic Sea even if these areas were known to be sites for large numbers of wintering Long-tailed Ducks.

In the early 1990s, after the political changes in the region, it was for the first time possible to organize extensive offshore surveys of the wintering water- birds in the entire Baltic in 1992-1993. Maps and population estimates were produced for all important waterbirds (Durinck et al. 1994). A second survey of the entire Baltic was organized in 2007-2010, the SOWBAS-project ("Status of Wintering Waterbird Populations in the Baltic Sea"; Skov et al. 2011).

Analysis of the results from the SOWBAS-project showed a decrease in the wintering population of Long-tailed Duck in the Baltic of about 65\% since the surveys in 1992/1993, with important decreases also for other wintering seaducks (Skov et al. 2011). Marked decreases in numbers of the species were documented from all parts of the Baltic, including Sweden (Nilsson 2012). As a response to this decrease the species was red-listed and work with a single-species action plan was started by AEWA (African European Waterfowl Agreement).

To follow up the situation for the wintering waterbirds in the area a third all-Baltic survey was organized in the winter 2016. In the last few years the Midwinter Counts have been used as an important part of the indicator "Numbers and trends in breeding and non-breeding marine water birds" 
which is now accepted as a Core Indicator among a set of other indicators to monitor the situation in the marine areas of the European Union as a part of the MSFD (Marine Strategy Framework Directive). In this work offshore surveys of wintering water birds will be an important part in the future.

In this paper I analyze the results from the offshore surveys of Swedish waters in 2016 with the main focus on the Long-tailed Duck. Earlier, results from the boat surveys have been summarized by Nilsson (1980), whereas the aerial surveys under SOWBAS were presented by Nilsson (2012). The present paper updates the previous presentations of the development of the wintering populations and compares the winter distribution of the species from the last survey with the results from the previous surveys.

\section{Material and methods}

In 2016, as in the 2007-2011 surveys, the offshore areas were covered by line transects from an aircraft. The census lines were laid out so that all important water areas (including the offshore banks) in the Swedish part of the Baltic were covered out to a depth of about $30 \mathrm{~m}$. The survey lines started at the shore or, in the extensive east coast archipelagos (mainly the Stockholm archipelago), from the inner larger islands. Generally, there was a distance of $4 \mathrm{~km}$ between the survey lines but in some special areas (e.g. Hanö Bight and Falsterbo) there was a distance of $2 \mathrm{~km}$ between the lines. The survey lines are shown in the distribution maps from the surveys (Figure 2 for an overview and the regional maps).

For the surveys a Cessna 337 Skymaster, a twinengined high-winged aircraft with good visibility was used. The flying altitude was about $70 \mathrm{~m}$ and the speed $150-180 \mathrm{~km} / \mathrm{h}$, i.e. the slowest possible. Aerial surveys were only undertaken in good weather conditions. Fixed waypoints at the ends of each transect were established and navigation was undertaken with the aid of the GPS of the aircraft. Another GPS recorded the actual flight track taking positions every ten seconds. Two observers covered each side of the aircraft. All observations were recorded on tape with time and were later transferred to a database with the positions from the GPS recordings.

During the surveys in 2007-2011, all water birds were counted within a survey belt extending $200 \mathrm{~m}$ on either side of the aircraft. This means that we covered a zone $320 \mathrm{~m}$ wide as there was a dead angle below the aircraft. During SOWBAS distance sampling was not used but observations outside the survey belt was recorded as additional information. During the 2016 survey the data were recorded in three different bands to make the data collection more similar to the methods used in the other countries: A (=main band) out to $200 \mathrm{~m}, \mathrm{~B} 200-500 \mathrm{~m}$ and C 500-1000 m. In $2007-$ 2011 , counts were only made in the main band.

The counts from the line transects were used to estimate regional totals for the different species using the counts within the main band of the surveys and a factor based on the coverage of the different regions $(6.25$ and 12.5 , respectively for transects separated by 2 and $4 \mathrm{~km}$ ). For some areas with very marked differences in densities of different species between areas a stratified sampling routine separating low and high density areas was used in the calculations. Even if data were collected from three different bands in 2016, I only used the data from the main band in the calculations presented here to make the results from the surveys in 2007-2011 and 2016 comparable with each other.

In 2016, the offshore areas from Falsterbo in the southwest to the Gävle Bight in the north were covered with transect lines (Figure 2). In the south, some transects in the Öresund could not be surveyed due to flying restrictions in the Control Area of Copenhagen airport. Moreover a few lines in the Stockholm archipelago were not flown as planned partly due to military activities. The differences in coverage was compensated for in the calculations.

The total area was surveyed during ten days between mid-January and mid-March 2016. The total flying time was 65 hours, of which 43 hours were used for actual bird counts. The 2016 winter was mild and there was no ice in the outer marine areas during the survey and only some ice in the inner parts of the archipelagos.

The surveys in the archipelagos in 2016 only covered the outer part with potential areas for species like the Long-tailed Duck. The inner parts of the archipelagos were covered by aerial surveys in the winter 2015. The surveys in the Stockholm archipelago 2015 covered the entire survey lines from the mainland coast to the outer skerries and will be included in the analysis presented here when it comes to distribution. For information about the earlier surveys used in the comparisons see Nilsson $(1980,2012)$.

\section{Results}

The national picture

At the first total survey of the Baltic in 1992/1993 (Durinck et al. 1994), the wintering population of Long-tailed Duck in Swedish waters was esti- 


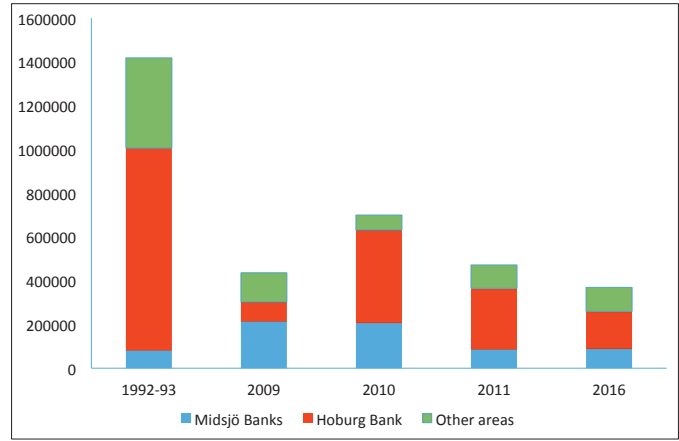

Figure 1. Estimated total numbers of wintering Long-tailed Ducks Clangula hyemalis in Swedish waters at the countrywide surveys shown separately for the important offshore banks and the other areas. A regional break-down is presented in Table 1.

Beräknat antal övervintrande alfåglar Clangula hyemalis I svenska vatten vid de landstäckande inventeringarna uppdelat på de viktiga bankarna samt övriga områden. En uppdelning på olika regioner återfinns $i$ Tabell 1. mated to be 1.4 million (Figure 1, Table 1). At the SOWBAS survey in 2009, the estimated total for Sweden was 436,000 individuals. As for the entire Baltic (Skov et al. 2011) this was a very marked reduction of the population. Numbers were higher at the 2010 survey with an estimate of 700,000 individuals. 2010 and 2011 were however hard ice winters and large important areas in the eastern part of the Baltic like the Riga Bay and Irbe Straits were ice-covered and the Long-tailed Ducks forced to move.

At the survey in 2016, the estimated population was lower still with 370,000 . Lacking data yet from the other countries it is difficult to establish whether there was a real decrease in wintering numbers or just a shift in the distribution to other areas in the Baltic.

In the mild winters of 2009 and 2016, the Longtailed Ducks were found all along the surveyed part of the Swedish Baltic coast (Figure 2). There was however a marked concentration to the three large offshore banks, Södra Midsjöbanken, Norra Midsjöbanken and Hoburgs Bank, where about $70 \%$ of all Long-tailed Ducks were found in both years. On the other hand, the Long-tailed Ducks were much

Table 1. Estimated totals of wintering Long-tailed Ducks Clangula hyemalis in different areas along the coasts of Sweden.

Uppskattat antal övervintrande alfäglar Clangula hyemalis in different areas along the coasts of Sweden.

\begin{tabular}{lrrrrrrr}
\hline Area & $1970-74$ & $1992-93$ & 2007 & 2009 & 2010 & 2011 & 2016 \\
\hline Falsterbo + S Öresund & & 500 & & 1600 & 2800 & 1200 & 900 \\
Scania south coast & 10000 & 800 & & 1700 & & 2000 & 4300 \\
Scania southeast & & 200 & & 100 & & 300 & 400 \\
Hanö Bight & 25000 & 17000 & 23000 & 17000 & & 7100 & 7200 \\
Blekinge archipelago & 1600 & 1100 & 300 & 100 & & 100 & 200 \\
Kalmarsund & & 12000 & 23000 & 11000 & 11500 & 2500 & 5800 \\
Öland east coast & 40000 & 10000 & 19000 & 26000 & & 39000 & 9100 \\
Ölands northern banks & 60000 & 30000 & 11000 & 5000 & 7200 & 22400 & 3500 \\
Midsjö banks & & 81000 & & 213000 & 206000 & 85000 & 87200 \\
Hoburgs bank & & 925000 & & 90000 & 426000 & 280000 & 173000 \\
Gotland east coast & 400000 & 270000 & & 11000 & 15100 & 15700 & 11800 \\
Gotska sandön + northern banks & 20000 & 10000 & & & 13500 & 14500 & 3900 \\
Gotlands west coast) & & 23000 & & 2000 & & 2000 & 6700 \\
Kalmar archipelago (N Kalmarsund) & 10000 & 12000 & & 14000 & 2700 & Ice & 1600 \\
Österg archipelago & 1000 & 3500 & & 8800 & 3200 & Ice & 6100 \\
Sörml. archiepalo & 4000 & 4000 & & 4100 & 12000 & Ice & 2400 \\
Stockholm archipelago & 24000 & 18000 & & 26100 & & Ice & 37000 \\
Uppland Northern coast & & & 3700 & & Ice & 2600 \\
Gävle Bight & & 1418100 & 600 & & Ice & 5800 \\
\hline Total & & & 435800 & 700000 & 471800 & 369500 \\
\hline
\end{tabular}




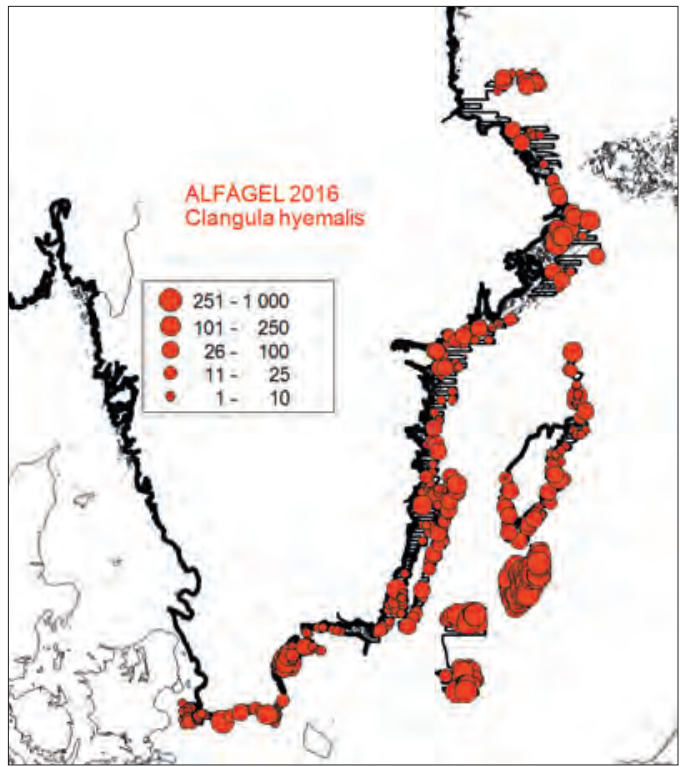

Figure 2. The distribution of Long-tailed Ducks Clangula hyemalis in Swedish waters during the winter 2016. Black lines in this and following maps show the flight tracks of the aerial surveys.

Utbredning för alfågel Clangula hyemalis i svenska farvatten vintern 2016. Svarta linjer i denna och följande kartor visar den aktuella rutt som flugits.

more concentrated in the ice-winters 2010 and 2011 (Nilsson 2012), with 90\% seen on the banks in 2010, a winter with heavy ice coverage in the Baltic.

\section{Regional pattern}

Small groups and a few larger flocks were found in the southern parts of the Öresund and along the south and southeast coasts of Scania (Figure 3). The total estimate for the area was 4300 in 2016 to be compared to about 10,000 or more during the 1970s. Three surveys during the SOWBAS-survey

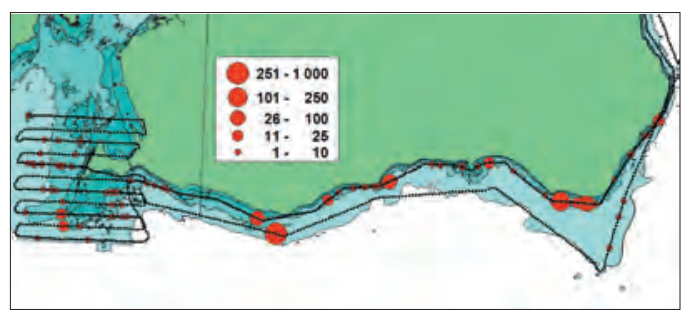

Figure 3. Distribution of Long-tailed Ducks Clangula hyemalis at the south coast of Scania in 2016.

Utbredning för alfågel Clangula hyemalis vid den skånska sydkusten 2016.

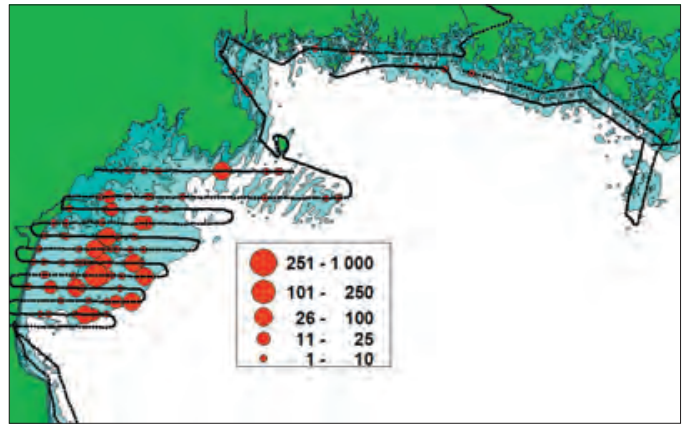

Figure 4. Distribution of Long-tailed Ducks Clangula hyemalis in the Hanö Bight in 2016.

Utbredning för alfågel Clangula hyemalis $i$ Hanöbukten 2016.

showed similar distributions (Nilsson 2012). During the sixties and seventies the species was more common in the area with up to a few thousand also in inshore waters (Nilsson 1972, 1980).

The Hanö Bight has been well-known as the southernmost concentration area for Long-tailed Ducks in Sweden with the majority of the birds concentrated to vast shallow areas in the western offshore part of the bight (Figure 4), whereas only very few individuals were seen in the outer parts of the Blekinge archipelago further to the east. During the early years of the study about 25,000 Long-tailed Ducks were estimated to winter in the Hanöbukten area but numbers decreased to about 7000 during the last two surveys. During the sixties and seventies flocks were also regularly seen in the outer parts of the Blekinge archipelago with an estimated total of about 2000 but in more recent years, numbers were appreciably lower here (Table 1).

The Kalmarsund and especially the waters east and north of Öland are important areas for wintering Long-tailed Ducks (Figure 5). Numbers in the Kalmarsund have been quite variable between 2500 and 23,000 during the recent surveys but the area will quite easily get ice-covered (Table 1 ). The areas east and north of Öland belong to the more important winter areas for the species close to the mainland. Rough estimates from the 1970s indicate that the population then could have been as high as 100,000 , but recent estimates are much lower and in 2007-2016 it varied between 13,000 in the mild winter of 2016 and 61,000 during the cold ice-winter 2011, when Kalmarsund and most archipelagos were ice-covered.

As stated above the offshore banks, Midsjö Banks and Hoburg Bank, are the most important Long-tailed Duck areas in Swedish waters with 

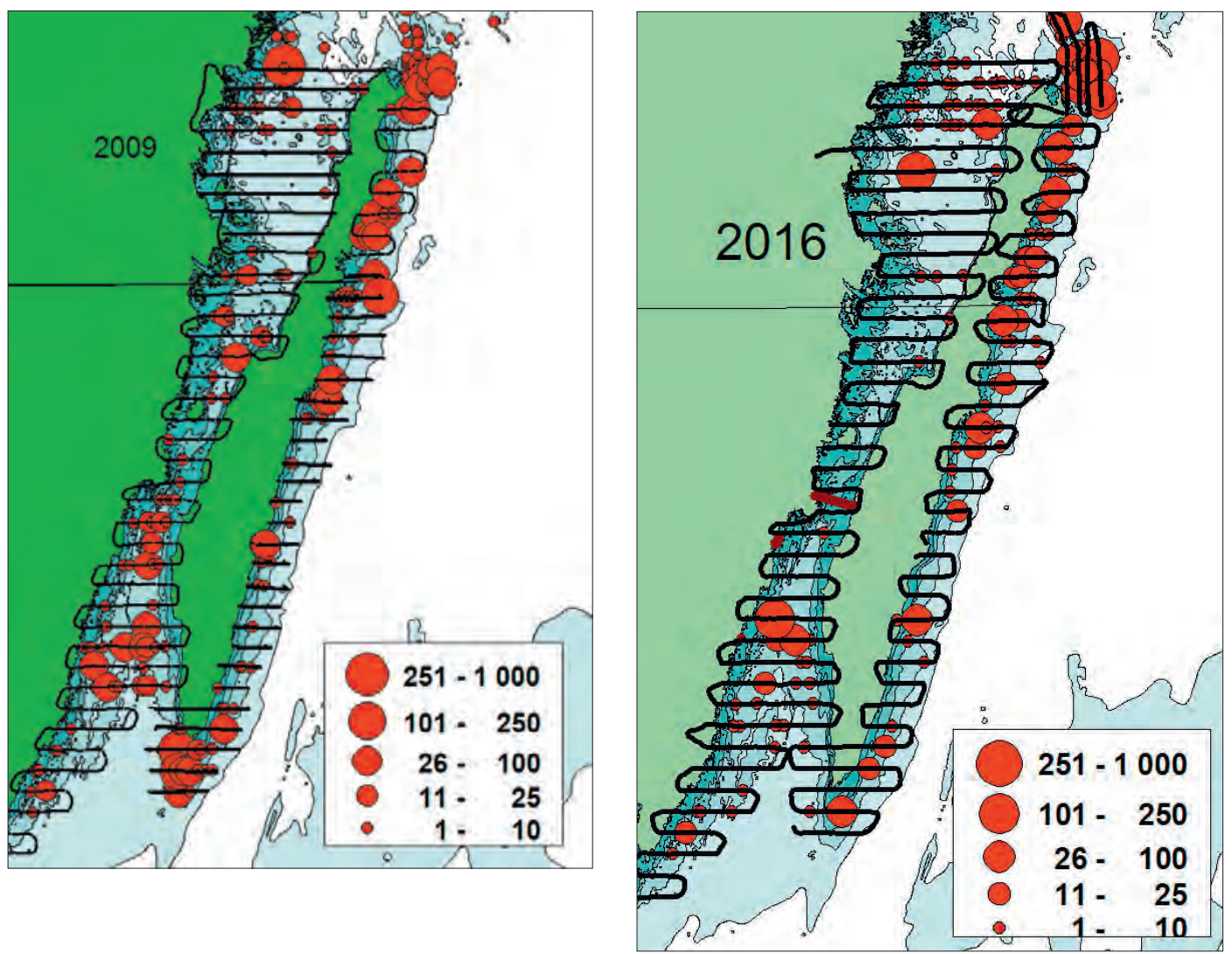

Figure 5. Distribution of Long-tailed Ducks Clangula hyemalis in the Kalmarsund and around Öland in the winters of 2009 and 2016.

Utbredning för alfågel Clangula hyemalis i Kalmarsund och runt Öland vintrarna 2009 och 2016.

about $70 \%$ of the total Swedish wintering population in normal winters and up to $90 \%$ during one of ice winters. The local distribution of the Longtailed Ducks on the banks are illustrated by the counts in the normal winters (Figure 6 for the Midsjö Banks and Figure 7 for Hoburg Bank).

During the years 2009-2016, the Midsjö Banks have been covered by aerial surveys at six different occasions with the total numbers varying between 44,500 and 213,000 individuals (Table 2). At the first Baltic survey in 1992/1993 the number of Long-tailed Ducks on the Midsjö Banks was estimated to be 81,000 . For Hoburg Bank the estimates for 2009 to 2016 varied between 90,000 and 426,000 , the highest total was obtained for the icewinter 2010, when the east coast of the Baltic was mostly ice-covered. In 1992/1993 the estimate for Hoburg Bank was no less than 900,000 Long-tailed Ducks. Unfortunately, there are no older censuses available from these important off-shore banks.
The coasts of Gotland are important areas for wintering Long-tailed Ducks (Figure 8) with many flocks occurring along all parts of the island except at the steep coasts of NW Gotland where flocks are fewer and smaller. The banks between northern Gotland and Gotska Sandön have historically been important for the Long-tailed Ducks.

During the years 2009 to 2016 the estimates from four surveys has varied between 11,000 and 16,000 for the entire east coast. The banks north of Gotland were surveyed in 2010, 2011 and 2016 with 13,500 and 14,500 Long-tailed Ducks found for the first two winters but less than 4000 in 2016. At the surveys in 1992/93 no less than 270,000 were estimated for the east coast of Gotland.

Unfortunately, there are very few historical data from the offshore areas east of Gotland but there is some information from a few coast guard patrols in the area. At one of these patrols to the areas around Fårön in NE and neighboring areas, the observers 


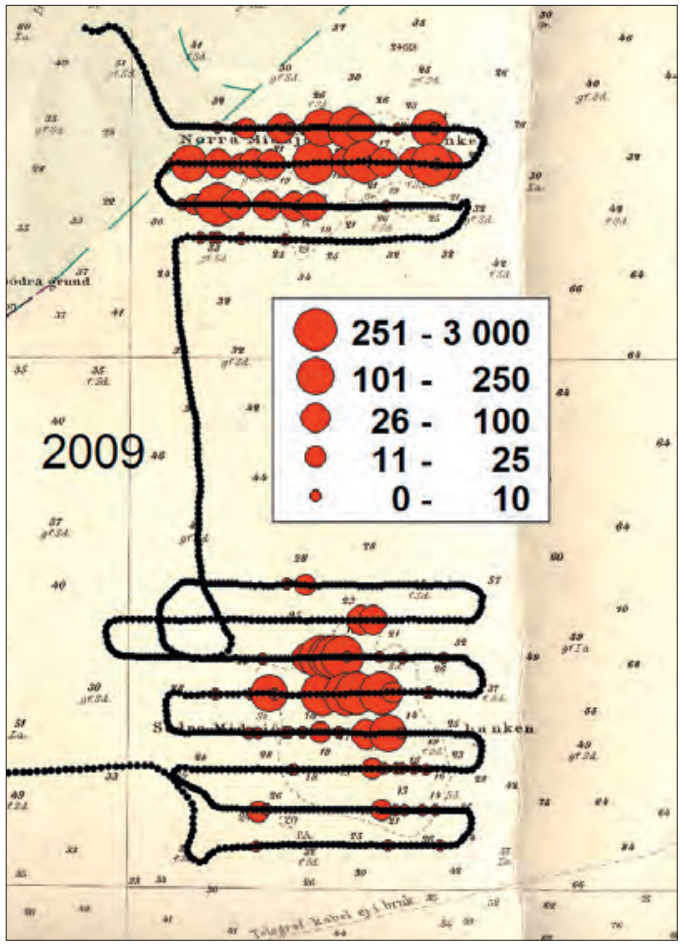

Figure 6. The distribution of Long-tailed Ducks Clangula hyemalis on the Midsjöbanks during the mild winters 2009 and 2016.

Utbredning för alfågel Clangula hyemalis på Midsjöbankarna under de milda vintrarna 2009 och 2016.

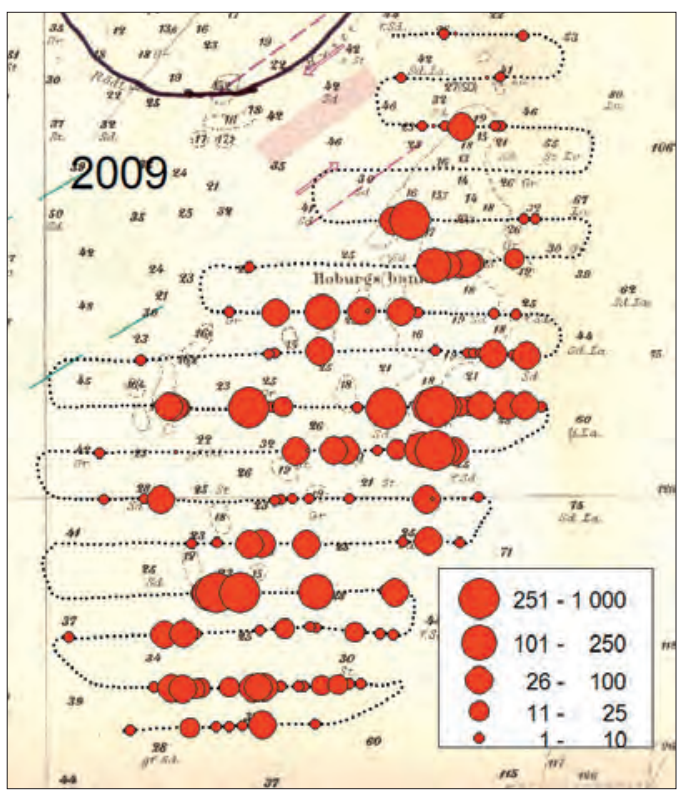

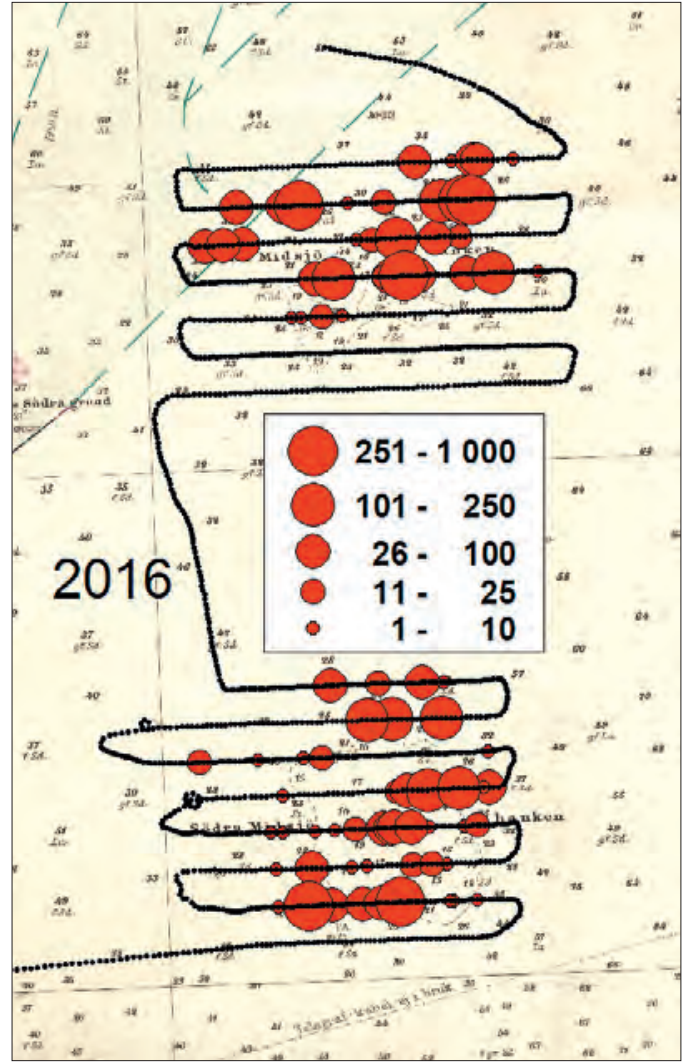

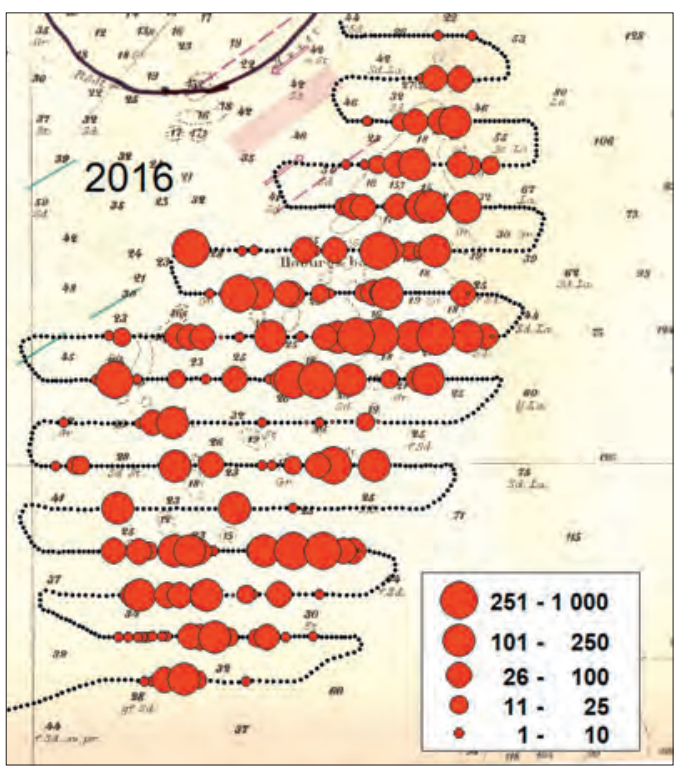

Figure 7 The distribution of Long-tailed Ducks Clangula hyemalis on Hoburgs Bank during the mild winters 2009 and 2016 Utbredning för alfågel Clangula hyemalis på Hoburgs Bank under de milda vintrarna 2009 och 2016. 
Table 2. Estimated totals of wintering Long-tailed Ducks Clangula hyemalis on the two Midsjö Banks at the different occasions when the banks were surveyed from the air.

Uppskattat antal övervintrande alfåglar Clangula hyemalis vid Midsjöbankarna vid de olika tillfällen bankarna flyginventerats.

\begin{tabular}{lrrrrrrr}
\hline & $2005-04-01$ & $2009-03-03$ & $2010-03-16$ & $2011-03-07$ & $2011-03-29$ & $2011-04-20$ & $2016-02-24$ \\
\hline Northern & & 76000 & 74000 & 63000 & 37000 & 67000 & 56700 \\
Southern & 160000 & 137000 & 132000 & 22000 & 7500 & 16500 & 34500 \\
\hline Total & & 213000 & 206000 & 85000 & 44500 & 83500 & 91200 \\
\hline
\end{tabular}

actually counted 70,000 from the ship. Based on densities obtained from the coast guard patrols and one aerial reconnaissance flight in 1974, the wintering population of the Long-tailed Duck in the offshore areas east of Gotland is roughly estimated to have been in the order of 400,000 in the early seventies (Nilsson 1980). The total numbers wintering here in recent years may be as low as 5\% of the numbers during the early seventies.
The Long-tailed Duck is widely distributed in the archipelagos from Kalmarsund in the south up to and including the Stockholm archipelago (Figures 9-12). These areas were extensively covered from Coast Guard Patrols and area-based aerial surveys in the 1970s as well as by the aerial transects in later years. This offers good possibilities to compare the situation in the two time periods 1971-1978 and 2009-2016.
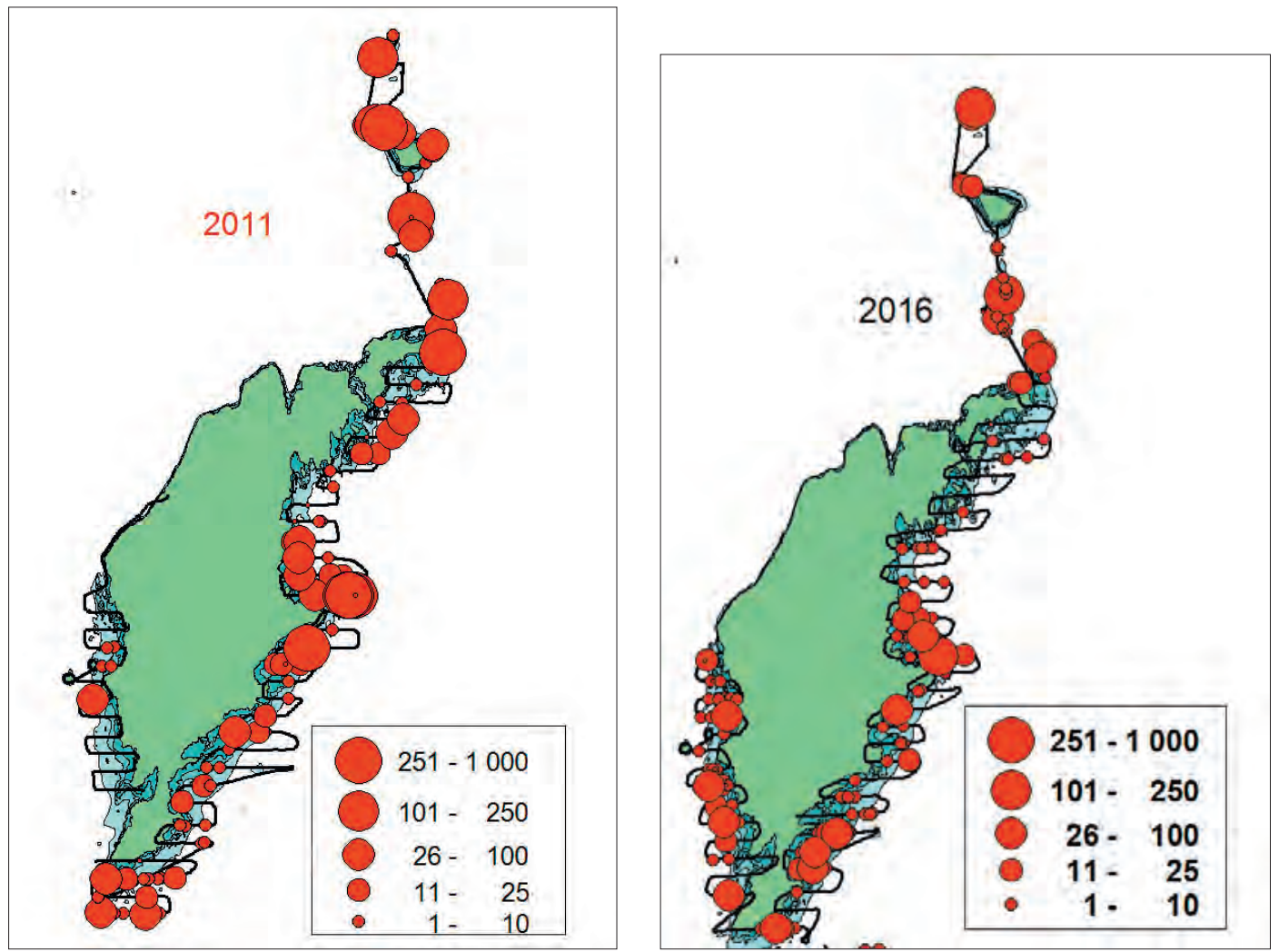

Figure 8. The distribution of Long-tailed Ducks Clangula hyemalis around Gotland in the winters 2011 and 2016. Utbredning för alfågel Clangula hyemalis runt Gotland vintrarna 2011 och 2016. 


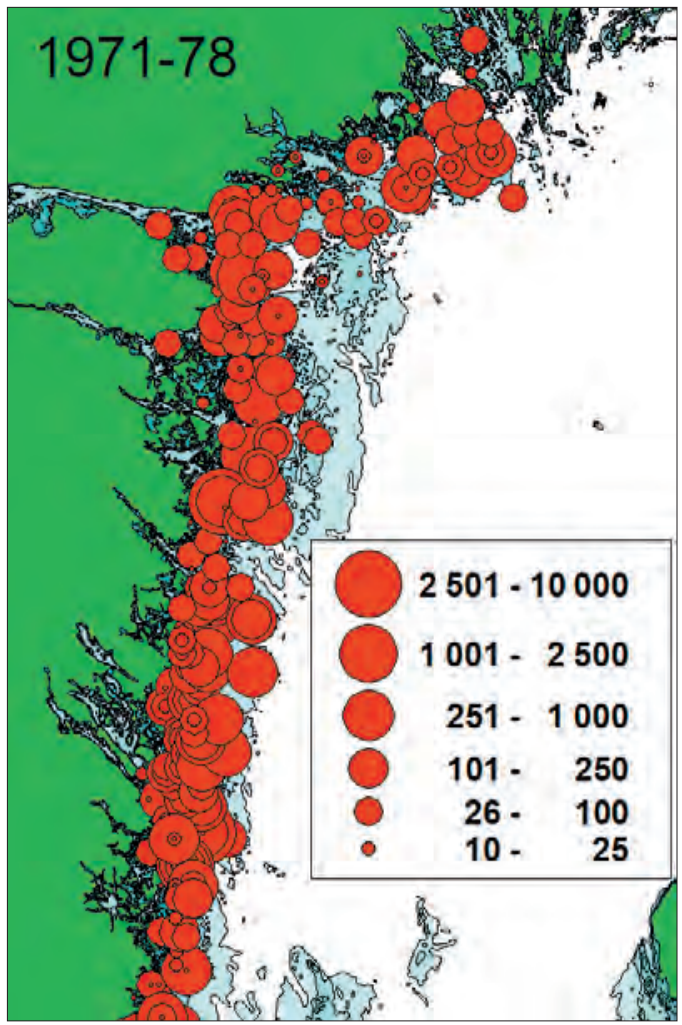

Figure 9. Distribution of wintering Long-tailed Ducks Clangula hyemalis in the archipelago areas of N. Kalmar, Östergötland and Södermanland counties. The map is based on accumulated boat and aerial surveys during $1971-78$. Utbredning för övervintrande alfåglar Clangula hyemalis i skärgårdarna av norra Kalmar, Östergötland och Södermanlands län. Kartan baseras på ackumulerade båt och flyginventeringar $1971-78$.

The archipelagos of Kalmar, Östergötland and Södermanland counties (Figures 9, 10) are rather narrow. In the 1970s Long-tailed Ducks were commonly found in the middle and outer parts of the archipelagos and the accumulated map (Figure 9) show occurrences of flocks along the entire coastline. In the later surveys in 2009 and 2016, flocks were found in all parts in 2009, whereas hardly any Long-tailed Ducks were found in some parts of the area in 2016. Compared to the 1970s, the Longtailed Ducks were more common in the outer parts of the island zone with fewer in the zone with skerries further out.

There were no marked changes in numbers between the seventies $(15,000), 1992 / 1993(19,000)$ and $2010(18,000)$ for these parts of the archipelagos (Table 1). On the other hand, about 27,000 were estimated for the area based on the aerial sur- veys in 2009 compared to less than 10,000 in 2016.

In contrast with the archipelagos discussed in the previous paragraphs, the Stockholm archipelago is much wider with a distance of up to $70 \mathrm{~km}$ from the mainland coast to the outer skerries in some parts. The Stockholm archipelago was also intensively surveyed from Coast Guard patrols and area-based aerial counts during the 1970s. In later years, one area-based survey (2004) and three transect counts were made of the Long-tailed Duck areas.

Comparing the distribution patterns in the 1970s and 2004-2016 based on the accumulated totals from all counts, some marked differences were found between the two time-periods (Figure 11). In 2004-2016 much smaller numbers of Longtailed Ducks were found in the southern parts of the archipelago compared to the 1970s. A similar difference was found for the outermost areas in the central part of the archipelago, where relatively few flocks were found in the later period. In both periods, the northern parts of the archipelago were important for the species, but more Long-tailed Ducks were found closer to the mainland in the latter period compared to the 1970s. Comparing the three years with transect surveys (Figure 12), the Long-tailed Ducks were more spread in 2009 than in 2015 and 2016, when a marked concentration was found in the central parts of the northern archipelago.

There were no clear changes in the number of wintering Long-tailed Ducks in the Stockholm archipelago between 1970-1974 and 2009, but in contrast to all other areas the highest estimate was obtained for 2016 (Table 1).

North of the Stockholm archipelago, Long-tailed Ducks were also found in winter along the coasts of Uppsala county and in the Gävle Bight (Figure 13). These areas were surveyed both in 2009 and 2016 with smaller numbers found scattered on the banks Finngrunden and in some parts of the archipelago. No historical data are available from this northernmost winter area of the species.

\section{Discussion}

The results of the censuses of Swedish offshore waters presented in this report and previous papers (Nilsson 2008, 2012) as well as the two international publications from the first two all-Baltic surveys (Durinck et al. 1994, Skov et al. 2011) clearly shows the importance of the Swedish offshore waters for the Long-tailed Duck, especially the importance of the three offshore banks: the Midsjö Banks and Hoburg Bank. The three banks together 

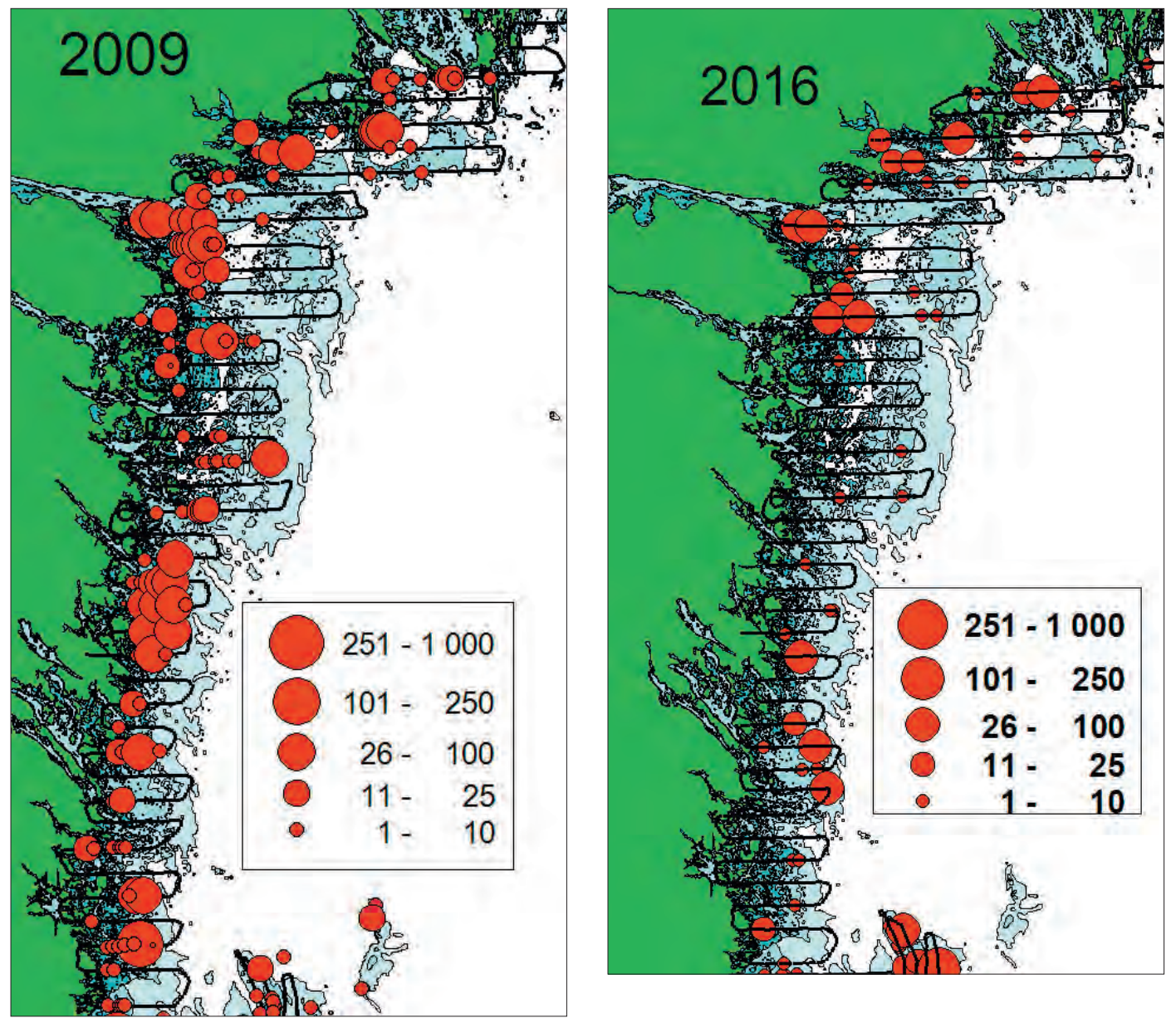

Figure 10. Distribution of wintering Long-tailed Ducks Clangula hyemalis based on aerial surveys in the counties of Kalmar, Östergötland and Södermanland in 2009 and 2016.

Utbredning för övervintrande alfåglar Clangula hyemalis i skärgårdarna av norra Kalmar, Östergötland och Södermanlands län. 2009 och 2016.

hold at least $70 \%$ of the Swedish Long-tailed Duck population in winter. During the first two all-Baltic surveys, the Swedish waters had about $30 \%$ of the total population, implying that the three offshore banks in the Swedish zone together harbors at least $20 \%$ of the total population and sometimes in hard winters even more (Nilsson 2012).

The previous all-Baltic survey in 2007-2009 showed a very marked decrease in the overall wintering population of Long-tailed Ducks since the first survey in 1992/1993 (Skov et al. 2011). Similarly, a marked decrease was found in the wintering populations in Swedish waters (cf. also Nilsson 2012). Between 2009 and the survey in 2016, the decrease continued and the Swedish wintering population was about $15 \%$ lower than in 2009. Until the international counts have been analyzed and made available it would however be premature to try to establish if this was a part of a general pattern or an effect of a redistribution.

In spring, the Long-tailed Ducks migrate to the breeding areas in northern Russia, a major part of the population passing the Gulf of Finland during their migration, large numbers of migrating Longtailed Ducks being counted from sites in Finland and Estonia during a restricted period (Bergman 1974, Hario et al. 2009). Counts at Söderskär on the Finnish coast showed an increase in the number of passing Long-tailed Ducks from about 1970 to the early 1990 s, followed by a marked decrease (Hario et al. 2009, see also Kauppinen \& Leivo 

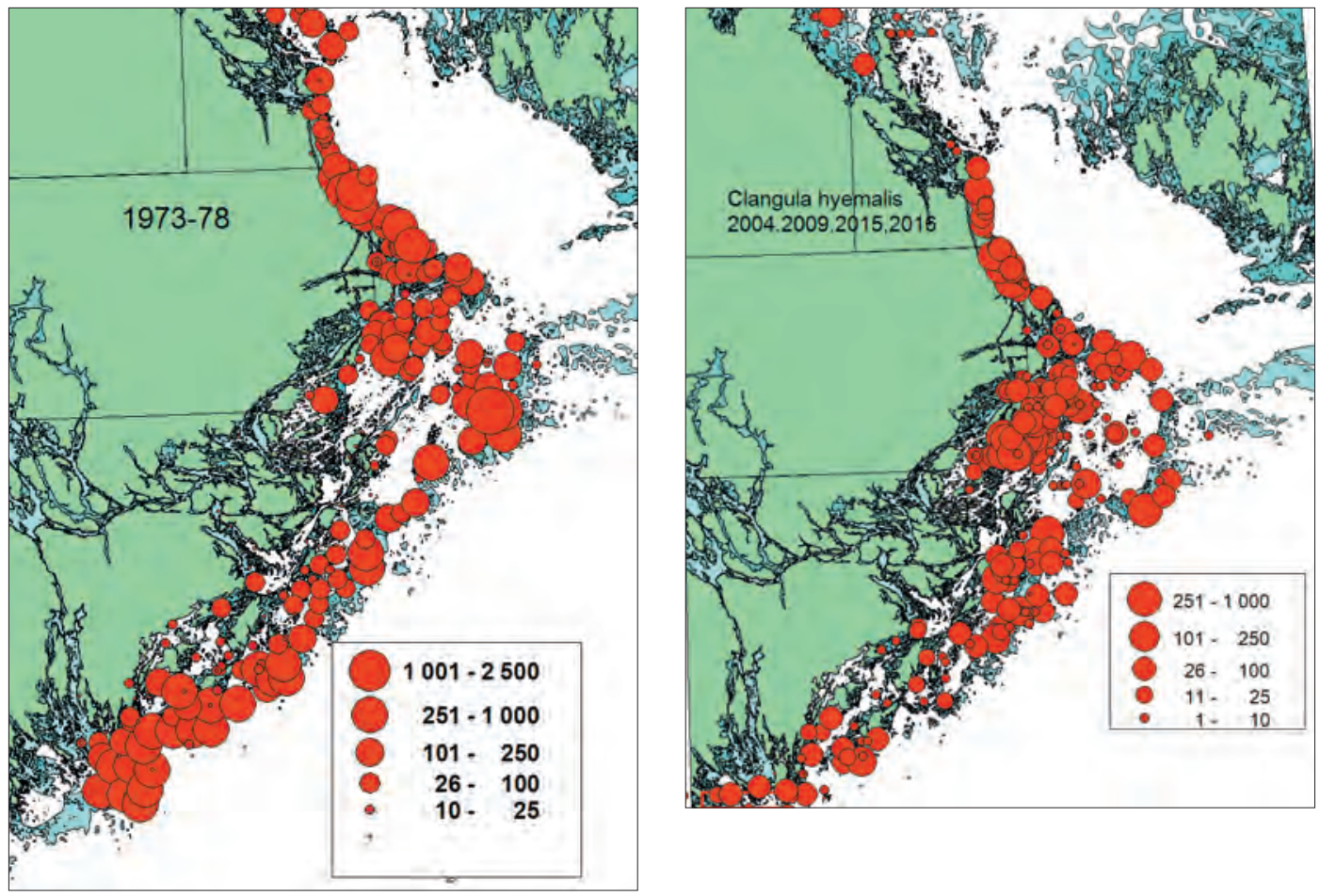

Figure 11. Distribution of wintering Long-tailed Ducks Clangula hyemalis in the Stockholm archipelago area. The maps are based on accumulated boat and area-based aerial surveys during 1971 - 78 and accumulated aerial surveys 2004 - 2016 . Note that aerial surveys in 2004 was area-based (cf. Nilsson 2008), whereas the surveys in 2009 - 2016 were transects (details seen Figure 12).

Utbredning för övervintrande alfåglar Clangula hyemalis i Stockholms skärgård. Kartorna baseras på ackumulerade båt och områdes-baserade flyginventeringar 1971 - 78och ackumulerade flyginventeringar 2004 - 2016. Observera att flyginventeringarna 2004 (jfr Nilsson 2008) var områdesbaserade, medan inventeringarna 2009 - 2016 var linjetaxeringar (detaljer se Figur 12).

2008). The highest counts of spring migrants coincided with the first all Baltic survey (1992/1993), which yielded much higher estimates than the 2007-2009 survey.

A regional breakdown of the census results from different time periods (Table 1) show marked differences in the population development between different Swedish regions. The most marked decrease was found for the areas east of Gotland also including the Hoburg Bank. Marked decreases were also found for the waters north and east of Öland but the magnitude of the decrease was much smaller than for the areas east of Gotland.

On the mainland coast, the Long-tailed Duck is found wintering in the outer parts of the archipelagos from the Kalmarsund in the south to the coasts of Uppland in the north. Numbers here are much smaller than at the offshore banks, but there was no clear trend in the wintering numbers taking the archipelagos as a unit. As a matter of fact, the numbers estimated for the Stockholm archipelago was the highest during the study. It may however be noted that wintering Long-tailed Ducks nearly disappeared from the inshore parts of the south coast of Sweden during the study period.

Different factors have been discussed in relation to the decline such as oil pollution, bycatches in fishing equipment and decreased habitat quality (Larsson \& Tydén 2005, Stempniewicz 1994, Mathiasson 1970, Skov et al. 2011, Zydelis et al. 2009) and probably the decline is caused by a combination of different factors. The regional differences in the extent of the decline in Swedish waters with the most marked decline for the waters east of Gotland is however a strong indication that oil pollution is an important factor behind the decline. These areas are close to the main shipping line through the Baltic to St Petersburg and other im- 

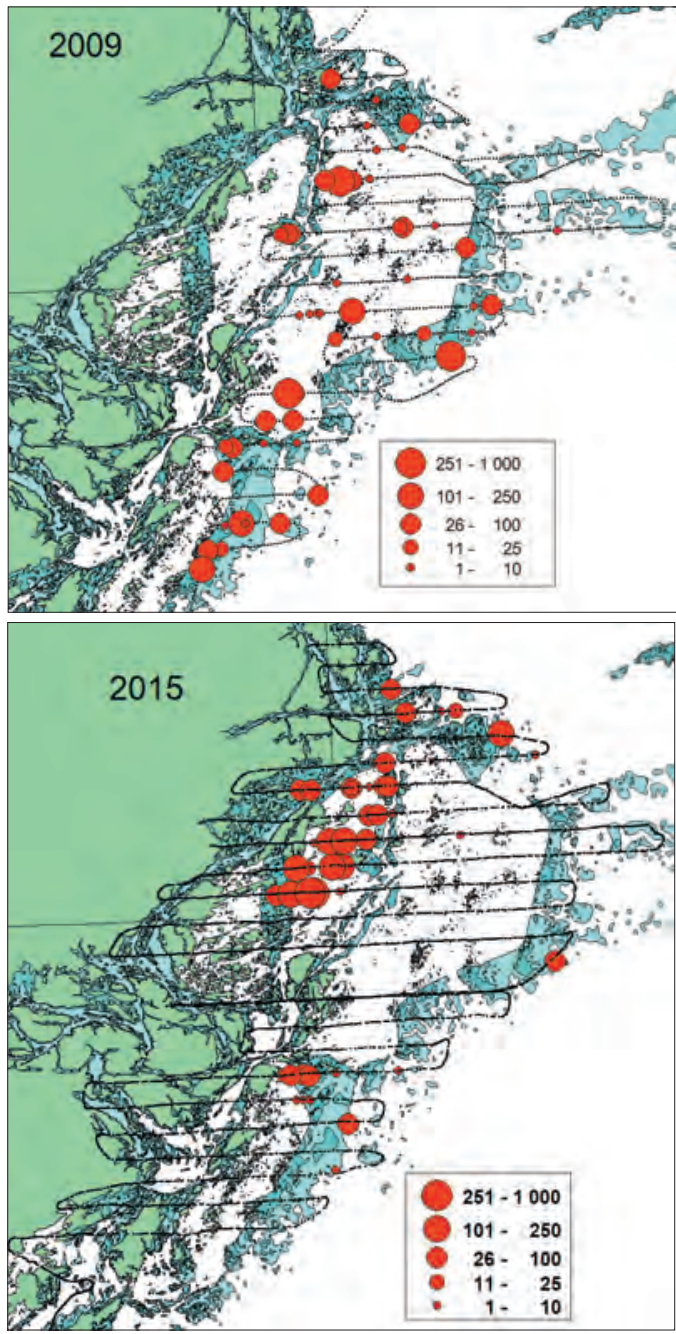

portant cities in the eastern part of the Baltic. There is also an extensive but illegal cleaning of the tanks offshore with regular small oil spills at sea.

\section{Acknowledgements}

The offshore aerial surveys reported here as well as the Swedish Midwinter Counts are supported by grants from Naturvårdsverket (the Swedish Environmental Protection Agency). The same applies to the aerial surveys in the seventies which were also supported by the Swedish Airforce, which provided free flying time. I am also grateful for the support of the Swedish Coast Guard that allowed duck counters onboard their patrol ships during the surveys in the sixties and seventies.

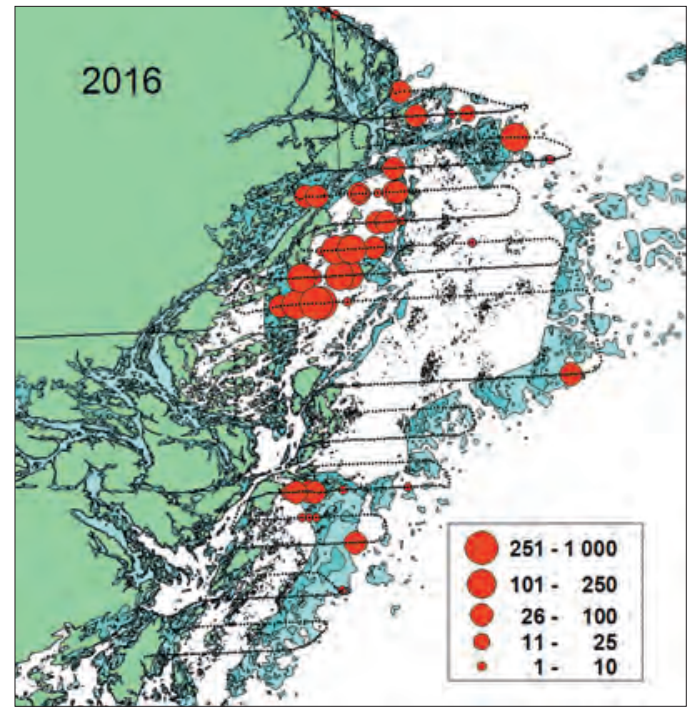

Figure 12. Distribution of wintering Long-tailed Ducks Clangula hyemalis based on aerial surveys in the Stockholm archipelago in 2009, 2015 and 2016.

Utbredning för övervintrande alfåglar Clangula hyemalis baserad på flyginventeringar i Stockholms skärgård 2009 2015 och 2016.

The aerial surveys could not have been done without the help of a number of skilled observers and I will give my sincere thanks to David Erterius, Martin Granbom, Martin Green, Fredrik Haas, Nils Kjellen, Johan Nilsson, Gabriel Norevik, Roine Strandberg and Mikael Svensson for many observer hours over the open sea

\section{References}

Durinck, J., Skov,H., Jensen, F.P. \& Pihl, S. 1994. Important Marine Areas for Wintering Birds in the Baltic Sea. Ornis Consult, Copenhagen, Denmark.

Green, M. \& Nilsson, L. 2015. The importance of offshore areas in southern Öresund, Sweden for staging and wintering sea ducks. Ornis Svecica 25: 24-39.

Hario,M., Rintala, J. \& Nordenswan,G. 2009. (Dynamics of wintering long-tailed ducks in the Baltic Sea - the con- 

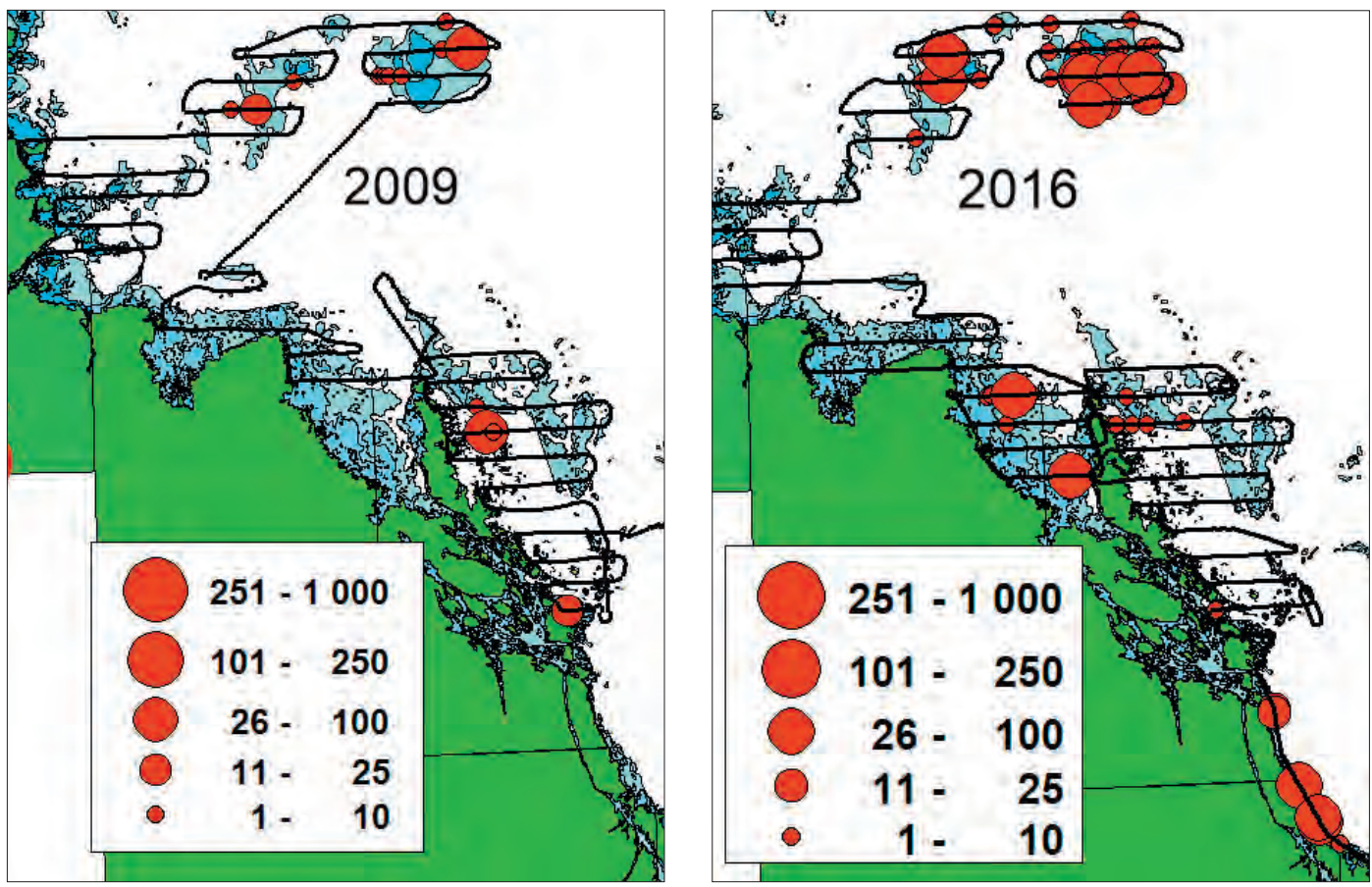

Figure 13. Distribution of wintering Long-tailed Ducks Clangula hyemalis based on aerial surveys in the county of Uppsala and the Gävle Bight in 2009 and 2016.

Utbredning för övervintrande alfåglar Clangula hyemalis i baserad på flyginventeringar i Uppsala län och Gävlebukten 2009 och 2016.

nection with lemming cycles, oil disasters and hunting). Suomen Riista 55: 83-96 (Finnish with English summary).

Kauppinen, T.J. \& Leivo, K.M. 2008. Vaimeneeko allin laulu? Suomen Luonto 2: 20-25. (In Finnish)

Larsson, K. \& Tydén, L. 2005. Effekter av oljeutsläpp på övervintrande alfågel Clangula hyemalis v id Hoburgs bank I central Östersjön mellan 1996/97 och 2003/04. Ornis Svecica 15: 161-171.

Mathiasson, S. 1970. Numbers and distribution of Longtailed wintering Ducks in northern Europe. British Birds 63: 414-424.

Nilsson, L. 1972. Habitat Selection, Food Choice and Feeding Habits of Diving Ducks in Coastal Waters of South Sweden during the Non-Breeding Season. Ornis Scandinavica 3: 55-78.

Nilsson, L. 1975. Midwinter distribution and numbers of Swedish Anatidae. Ornis Scandinavica 7: 193-205.

Nilsson, L. 1980. De övervintrande alfåglarnas Clangula hyemalis antal och utbredning längs den svenska kusten. Vår Fågelvärld 39: 1-14.

Nilsson, L. 2008. Changes in numbers and distribution of wintering waterfowl in Sweden during forty years, $1967-$ 2006. Ornis Svecica 18: 135-226.

Nilsson, L. 2012. Distribution and numbers of wintering sea ducks in Swedish offshore waters. Ornis Svecica 22: 39-59.

Nilsson, L. \& Green, M. 2011. Birds in southern Öresund in relation to the windfarm at Lillgrund. Final report of the monitoring program 2001-2011. Rapport från Biologiska Institutionen, Lunds Universitet.

Nilsson, L. \& Haas, F. 2016. Distribution and numbers of wintering waterbirds in Sweden in 2015 and changes during the last fifty years. Ornis Svecica 26: 3-54.

Skov, H., Heinänen, S., Zydelis, R., Bellebaum, J., Bzoma, S., Dagys, M., Durinck, J., Garthe, S., Grishanov, G., Hario, M., Kieckbusch, J.J., Kube, J., Kuresoo, A., Larsson, K., Luigujoe, L., Meissnerm, W., Nehls, H.W., Nilsson, L., Petersen, I.K., Roos, M., Pihl, S., Sonntag, N., Stock, A. \& Stipniece, A. 2011. Waterbird Population and Pressures in the Baltic Sea. Tema Nord 2011: 550.

Stempniewicz, L. 1994. Marine birds drowning in fish nets in the Gulf of Gdansk (southern Baltic): numbers, species composition, age and sex structure. Ornis Svecica 4: 123-132.

Zydelis, R., Bellebaum, J., Österblom, H., Vetemaa,M., Schirmeister, B., Stipniece, A., Dagys, M., can Eerden, M. \& Garthe, S. 2009. Bycatch in gillnet fisheries - An overlooked threat to waterbird populations. Biological Conservation 142: 1269-1281. 

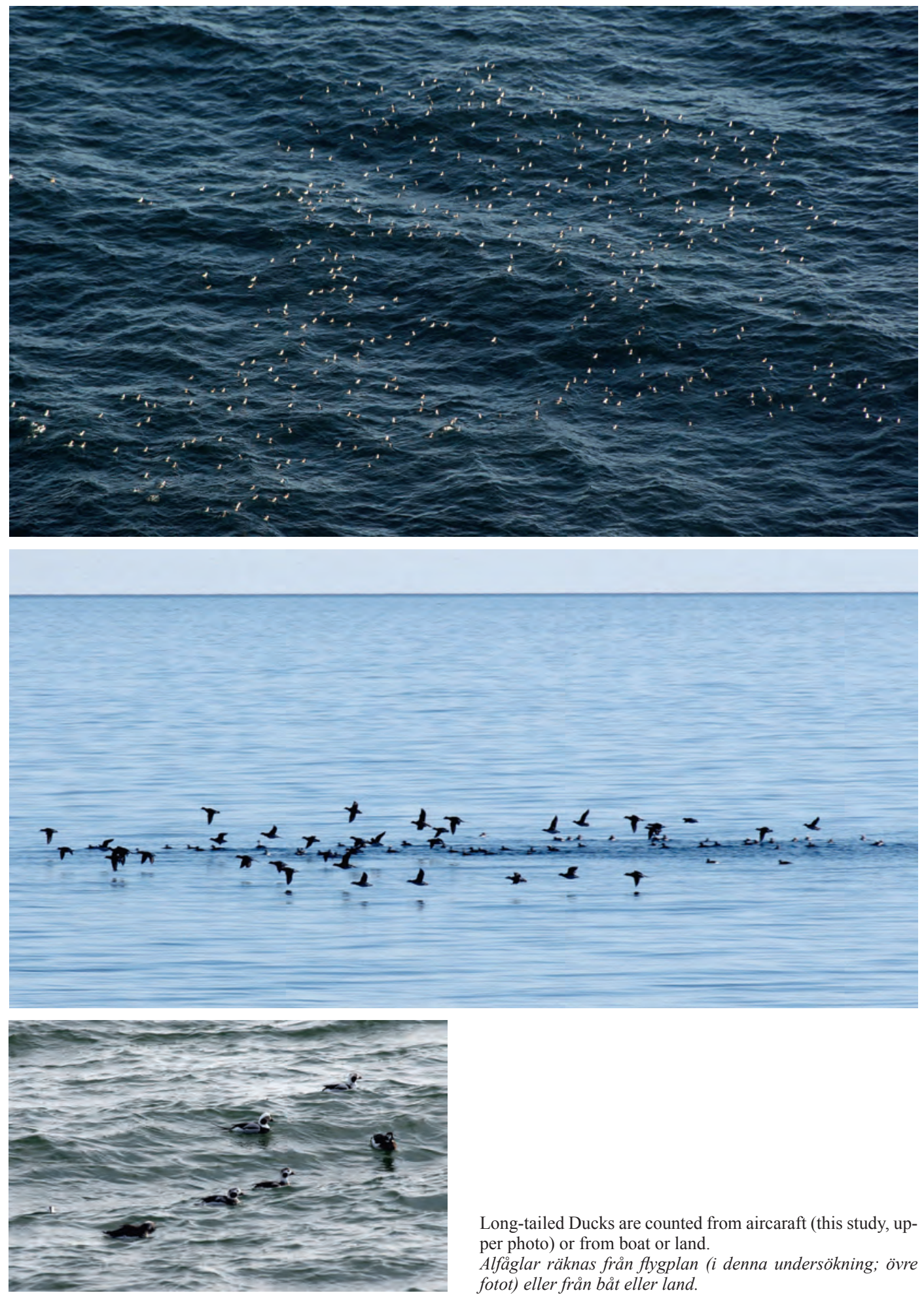

Long-tailed Ducks are counted from aircaraft (this study, upper photo) or from boat or land.

Alfåglar räknas från flygplan (i denna undersökning; övre fotot) eller från båt eller land. 


\section{Svensk sammanfattning}

Alfågeln är den vanligaste övervintrande andfågeln i de svenska farvattnen, men till följd av dess utbredning långt ute till havs, är den inte så väl täckt vid de regelbundna midvinterinventeringarna av sjöfåglar, som organiserats i Sverige och övriga Europa sedan 1967 (Nilsson 1980, 2012, Nilsson \& Haas 2016). Inventering av de övervintrande alfåglarna kräver speciella inventeringar av skärgårdarna och utsjöbankarna.

Under 1965-1978 genomfördes mer än 100 båtinventeringar runt kusterna från kustbevakningens båtar (Nilsson 1972, 1980). Omfattande flyginventeringar genomfördes också i skärgårdarna samt efter de öppna kusterna av Skåne, Öland och Gotland. Däremot var det inte möjligt at inventera utsjöbankar som Hoburgs Bank och Midsjöbankarna, även om dessa var välkända som viktiga lokaler för alfågeln.

I början av 1990-talet, efter de politiska förändringarna i området, kunde för första gången hela Östersjön inventeras med avseende på övervintrande sjöfåglar (Durinck et al. 1994). En ny stor inventering, den s.k. SOWBAS-inventeringen ("Status of Wintering Waterbird Populations in the Baltic Sea") genomfördes 2007-2011 (Nilsson 2012, Skov et al. 2011). Jämförelser mellan de två totalinventeringarna visade på en mycket markant nedgång av antalet övervintrande alfåglar i Östersjön. För att följa upp situationen organiserades en tredje heltäckande inventering 2016. Dessa sjöfågelinventeringar ingår numera i de indikatorer som utarbetats för Eus marina direktiv för att följa upp situationen i havsområdena.

I denna uppsats analyserar jag resultaten från offshore-inventeringarna i de svenska farvattnen 2016 med fokus på alfågeln. Tidigare resultat från de äldre inventeringarna har sammanfattats av Nilsson (1980), medan resultaten från SOWBASinventeringen presenteras av Nilsson (2012). Förutom att presentera de senaste inventeringsresultaten för alfågeln i de svenska farvattnen försöker jag också belysa utvecklingen under de senaste femtio åren mot bakgrund av de äldre inventeringarna.

\section{Material och metoder}

Vid inventeringarna 2016 liksom 2007-2011 täcktes de yttre svenska farvattnen och skärgårdsområdena med linjetaxeringar från flygplan. Inventeringslinjer lades ut med 2 eller $4 \mathrm{~km}$ mellanrum från kusten ut till ca $30 \mathrm{~m}$ djup på sådant sätt att alla potentiella områden för havslevande dykänder kunde täckas. Linjesystemet framgår av översiktskartan i Figur 4 och från de regionala kartorna.

Inventeringarna genomfördes med en högvingad tvåmotorig CESSNA 337-Skymaster. Flyghöjden var ca $70 \mathrm{~m}$ och hastigheten vid inventeringarna $180 \mathrm{~km} / \mathrm{tim}$. Två observatörer täckte var sin sida av planet. Observationerna registrerades i tre bälten: A ut till $200 \mathrm{~m}$, B 200-500 m och C 500-1000 m. Under planet fanns en död zon så det inre bältet täckte totalt en $320 \mathrm{~m}$ bred zon. Navigeringen baserades på fasta "way-points" vid transekternas början och slut. Dessutom registrerades regelbundet positionerna var 10 sek. på en separat GPS.

Antalet sjöfåglar beräknades för de olika områdena genom att multiplicera vad som räknats inom band A med en faktor på 6,25 resp. 12,5 beroende på om linjerna låg 2 eller $4 \mathrm{~km}$ från varandra. I den här presenterade analysen utnyttjades endast observationer från bälte A eftersom endast detta bälte täcktes vid inventeringarna 2007-2011.

Vid inventeringen 2016 täcktes de yttre farvattnen från Falsterbo i söder till Gävlebukten i norr (Figur 2). I skärgårdarna inventerades endast de yttre delarna, medan de inre skärgårdsområdena inventerades 2015 (se Nilsson \& Haas 2016). Området inventerades under tio dagar mellan mitten av januari och mitten av mars. Den totala flygtiden var 65 timmar, varav 43 ägnades åt direkta fågelräkningar.

\section{Resultat}

Den nationella bilden

Vid den första totalinventeringen av Östersjön 1992/93 (Durinck et al. 1994), beräknades antalet övervintrande alfåglar i de svenska farvattnen till 1,4 miljoner (Figur 1, Tabell 1). Vid SOWBAS-inventeringen 2009 var motsvarande antal 436000. Liknande minskningar konstaterades överallt i Östersjöområdet. Den kalla vintern 2010 var antalet högre, ca 700000 i de svenska farvattnen, men då var de viktiga lokalerna vid Rigabukten och i öster istäckta.

Inventeringen 2016, som liksom 2009 genomfördes under en mild vinter, visade en beräknad summa för de svenska farvattnen på 370000 , en fortsatt nedgång. Det är dock omöjligt att avgöra om detta är en del av en allmän minskning eller om alfåglarna ändrat vinterutbredning till viss del, eftersom resultaten från övriga delar av Östersjön ännu inte presenterats.

Under de milda vintrarna noterades övervintrande alfåglar inom hela det inventerade området (Figur 1, se också Nilsson 2012). En mycket betydande del av beståndet var koncentrerat till de 
tre utsjöbankarna. Hoburgs Bank, Södra och Norra Midsjöbanken. Vid båda tillfällena återfanns ca $70 \%$ av alfåglarna på dessa tre bankar. Isvintern 2010 var koncentrationen till bankarna ännu mer markerad, $90 \%$ av beståndet låg här.

\section{Regionala mönster}

Den regionala fördelningen av de övervintrande alfåglarna vid den senaste inventeringen 2016 redovisas i en serie detaljerade kartor (Figur 3 -13), vilka där så är tillämpligt också visar utbredningen vid tidigare tillfällen.

Som redan nämnts har antalet alfåglar längs den skånska sydkusten minskat sedan starten av inventeringarna på 1960-talet och endast få ses numera i de strandnära vattnen. Flockar konstaterades dock i de yttre områdena. I Hanöbukten har alfåglarna karterats sedan 1960-talet. Utbredningen vid de senaste inventeringarna var densamma som vid de tidiga inventeringarna. Storleksordningen av beståndet höll sig också fram till de senaste inventeringarna, då en minskning noterades.

Vattnen i Kalmarsund och Öland utgör viktiga vinterområden för alfågeln (Figur 5). I Kalmarsund varierar antalet mycket beroende på isförhållandena, medan farvattnen öster om Öland, speciellt i den norra delen hyser större mängder. Grova skattningar från 1970-talet tyder på att antalet alfåglar här kan ha varit så högt som 100 000, medan sentida beräkningar visat på lägre tall, 13000 en mild vinter som 2016 och 61000 under en av isvintrarna.

Betydelsen för Midsjöbankarna och Hoburgs bank som alfågellokal har redan kommenterats. Området utgör tillsammans det absolut viktigaste området för arten med $70 \%$ av totalbeståndet under normala vintrar. Tyvärr saknas jämförelse inventeringar från tidigare år. Alfåglarna förekommer spridda över hela bankarna (Figur 6,7).

Gotland utgör också ett viktigt område för alfågeln med flera förekomster runt kusterna. Markanta nedgångar har observerats för detta område, där antalet vid inventeringarna 2009 och 2016 skattades till mellan 11000 och 16000 att jämföras med kanske 200000 1992/ 93 och troligen ännu fler på 1970-talet.

Ostkust skärgårdarna norr om Kalmarsund utnyttjas regelbundet av övervintrande alfåglar. Skärgårdarna i Kalmar, Östergötland och Södermanlands län är mindre djupa än Stockholms skärgård. Hela detta skärgårdsområde inventerades intensivt också under 1970-talet från kustbevakningens båtar och från flyg, varför det finns goda möjligheter att jämföra utbredningen mellan dessa tidiga inventeringar och inventeringarna 2009-2016 (Fi- gur 9-12). En hel del skillnader noterades också i utbredningen mellan perioderna för Stockholms skärgård (Figur 11, 12).

Antalsmässigt förekom inga större skillnader $\mathrm{i}$ antalet alfåglar efter kusterna i de sydligare ostkustskärgårdarna fram till och med 2009, men 2016 var antalet i dessa tre län väsentligt lägre än tidigare. I Stockholms län noterades däremot inga skillnader i antalet övervintrande alfåglar mellan de olika perioderna, enbart en del variation. Antalet övervintrare 2016 var det högsta noterade för området.

\section{Diskussion}

De här presenterade inventeringarna liksom tidigare publicerade äldre inventeringar (Nilsson 2008, 2012) visar tydligt tillsammans med rapporterna från Östersjöinventeringarna (Durinck et al. 1994, Skov et al. 2011) Sveriges betydelse för de övervintrande alfåglarna i Europa och Östersjön i synnerhet. Totalt återfanns ca $30 \%$ av alla Östersjöns alfåglar i de svenska farvattnen, varav $20 \%$ på Midsjöbankarna och Hoburgs Bank.

De redovisade internationella inventeringarna liksom de här och tidigare (Nilsson 2012) redovisade svenska inventeringarna visar klart på en markant nedgång i antalet övervintrande alfåglar, en minskning som fortsatt till 2016. Det är emellertid oklart om den senaste minskningen i svenska vatten återspeglar en generell minskning eller endast en omfördelning av utbredningen. Minskningen från 1990-talet återspeglas också i sträckräkningar från Finland (Hario et al. 2009, Kauppinen \& Leivo 2008).

Minskningen i antalet övervintrande alfåglar är inte densamma inom hela det svenska övervintringsområdet utan är mest markant för områdena öster om Gotland, men återfinns också utanför Öland. Däremot har endast mindre förändringar eller enbart fluktuationer noterats för kustområden och skärgårdar, där antalet övervintrande alfåglar dock är betydligt lägre. Tyvärr saknas äldre data från de viktiga utsjöbankarna.

Orsakerna till den markanta nedgången är omdiskuterad. Olika faktorer såsom bifångst vid fiske, oljeföroreningar samt minskad kvalité på födosöksområdena har diskuterats (Larsson \& Tydén 2005, Stempniewicz 1994, Mathiasson 1970, Skov et al. 2011, Zydelis et al. 2009), men troligen har vi en påverkan av flera olika faktorer. Det faktum att den mest markanta nedgången noterats för farvattnen öster om Gotland ger dock en stark indikation på att faktorer som diffusa oljeutsläpp i den viktiga sjöfartslinjen öster om Gotland kan vara en viktig påverkansfaktor. 